\title{
TOURISM IN A NEW BRAVE WORLD: From the Inflation of Risk towards the Stock and Market Crisis
}

\author{
Korstanje Maximiliano \\ University of Palermo, Argentina, \\ Visiting Lecturer CERS, University of Leeds, United Kingdom. \\ Lourdes Cisneros Mustelier
}

University of la Habana Cuba

\begin{abstract}
The recent inflation of risks together the stock and market crises that shocked the world suggest that tourism has been stagnated over recent years. If tourism served to facilitate globalization, it is clear how a much deeper process of re-feudalization emerged. If our grandparents enjoyed holidays after hard work, we ask for financial loans to access the dream destinations. The exhaustion of economy is based not only on the exploitation of capitalist system, but in its collapse. This essay review explores the end of tourism as it has been formulated by Urry and Gale under the lens of scrutiny, but keeping in mind that Empires and tourism were historically intertwined.
\end{abstract}

Keywords: Mobilities, Tourism, Empires, Capitalism, End of tourism, Terrorism.

\section{INTRODUCTION}

Although tourism seems to be a globalized and growing industry dotted of a great resiliency to face disasters as earthquakes, floods, virus outbreaks and even terrorist blows, no less true is that some indicators show that we are next to the end of tourism. Policy-makers today not only are urged to answers problems generated in other geographical points or by other agents who are external to tourist system, but also are tested to offer innovative solutions to slippery matters. Tourist experts have no real solution to deter terrorism, but should deal with the idea a next attack can suddenly happen anytime and anywhere, which means that the urgency of policy makers to present competitive products is conducive to the attractiveness these places cultivate for terrorist. Security and safety have been posed as the main interests for international demand. This happens because of two main reasons. At a first glance, unlike our grant-parents, we are accustomed to follow our curiosity at time holidays. The quest for novelty or something new has transformed in the primary motive of holidays. Secondly, quite aside from these heritage seekers, tourism has consolidated as one of the most important industries of the world. As a result of this, some cells have acknowledged that the fact of killing tourists is a useful tool to create political instability. Once the credibility of state is seriously affected, their demands would be echoed in an easier way. Sociologically speaking, the anatomy of nation-state was based on welfare paradigm, where officialdom understood that intervention was an efficient instrument to prevent risks, and uncontemplated dangers, leading society towards a zero-risk atmosphere. From the end of WWII, industrial societies appealed to the conception of risk-zero programs, which proclaimed that rational planning aimed at protecting the citizenry may eradicate risks to make from our neighborhoods a safer place to dwell on. Not only this not happen, but the decline of Soviet Union, the globalization of economies accelerated the complexity of a system which shows serious problems to mitigate the negative effects of risks, even these risks are generated by the introduced technology by West. A type of Run-away modernity in terms of Giddens (1999) paves the ways for new fears and problems that affected the functionability of tourism industry as never before. The experts and planners devoted considerable attention to promotes programs or models that help nuancing the effects of sudden disasters (Pforr \& Hosie, 2009; Ritchie, 2004; 2009; Korstanje, 2011b; Blake \& Sinclair, 2003; Cohen \& Neal, 2010). In view of the limited time and space, this essay review does not focus on the connection of globalization with modernity, but explores to what extent risk perception is enrooted in the process of communication. In the discussion the goals are twofold, on one hand, we review the existent literature in risk perception theory applied in tourism, but at the same time we alert on the exhaustion of tourism. As Gale (2008) noted, we are living in a world where tourism is dying. 


\section{GLOBALIZING RISK}

Undoubtedly, the question of risk is discussed along with two contrasting poles. Culturalists will emphasize on the social nature of risk, while probabilists will delve into the algorithms that help preventing the negative effects of risks. In this vein, perception plays a crucial role by configuring the state of alarm of human mind. As Quarantelli put its (1975; 1982; 1990; 2001), not surprisingly psychology found now that attention, commitment and emotions are of paramount importance to understand why some events are over-valorized while others simply ignored. He reminds the paradox given by the earth-quake which hit Los Angeles in 1979 where the audience, convoked to enjoy of a football encounter, ignored the tremor because the game reached its zenith. This reminds that cognitive attention and the signs of dangers do not correspond with reality in some circumstances. In perspective, this global world has engendered a new cosmology where ordinary person feel nobody is safe anywhere and anytime. In fact, the efforts aimed to keep under control the states of emergency, as the case of Fukushima, may cause parallel effects. Sociologists agree that the production of knowledge as well as the shortly-time events are covered and disseminated in the world -by the media- over-stimulates a risk- centered prone that leads state to conduct populist programs to calm the anxiety of population (Sunstein, 2007). Instead of fixing the problem, as Sunstein put it, these programs, which are based on the precautionary principle, backfire.

As noted above, the problem of risks lingers for more than 40 years within social sciences. While psychology advanced to produce a coherent conceptual framework of the issue (Duclos 1987), sociology confirmed risks are culturally constructed in order for status quo`s legitimacy does not decline. As L Tierney observed, the great knowledge's dispersion generated caused a misleading interpretation of the issue, which today is very difficult to decipher. In sociology and anthropology, the term was introduced by Ulrich Beck respecting to the disaster of Chernobyl in Ukraine. If the classical economy proclaimed the use of technique as a valid instrument to prevent threats, this event showed the opposite. The same technology constructed to make the life of ordinary people safer, entrapped the society between the wall and blue sea. These new risks were engendered by the human technology (Beck, 2006). Following this reasoning, Beck clarifies that risk and modernity has been inextricably intertwined. The globalization of nations, their economies and boundaries created a more complex system where a subtle disruption may lead us to a catastrophe. The delocalization of the connectivity between reasons and effects has blurred the understanding of risk for modern experts; in a world, where the market destabilizes the social bond, the risk is the only reason for people to have communication (Beck, 2011). Not all sociologists agree with Beck's development. Niklas Luhmann (2006) adds that it is important to avoid the increasing sentiment of alarmism in social scientist, which is feed by the media and journalism. In doing so, one should distinguish the conception of risk and threat. The former signals only to the "principle of contingency", this means to the possibility for the subject to avoid the consequences of risk. Besides, risks are often resulted from a previous decision making process. In contrast to risks, dangers, which are external fabricated, are imposed to lay-people with less or no possibility to avoid its negative effects. The difference of both is very simple. Those peoples who made the decisions never face the risks these decisions created. An airplane accident is far for being a risk for lay passengers whose actions or ideas have not direct incidence in the misfortune. Since the responsibility is with the owners of air- company. Tourists only are passive agents who face the results of an outside danger. Luhmann acknowledges that not only the risks are generated by the elite, which never face its consequences, but social science alludes to a tactic of blaming the victim when misjudges the difference between risk and threat. Lay people in postmodernity are educated to think they are reliable for their decision, but they are not. The efficacy of capitalized modernity consisted in making believe that "self-management" is a good option towards progress (Luhmann, 2006). Anthony Giddens, another senior sociologist, would criticize Luhmann by two main reasons. Returning the ball to Beck, Giddens says that the dichotomy between risk and threats associated to decision making would be applicable only for Medieval Age. In the modernity, every subject is deciding, even deciding not to make a decision. So, risks are everywhere in our life no matter than our responsibility in their inceptions.

As the previous discussion given, a third alternative can be cited. Cass Sunstein (2006) conceives the inflation of risks as effects of bad decisions, which are the combination of two psychological mechanisms, the neglect of probability, and the heuristic of risk. The theory says that the risk assessment is previously determined by emotional disposition instead of rational evaluation cognitive activity-. The probability neglect exhibits sometimes people delve into the worst possible 
situation failing to inquire properly on real causes of dangers. This mechanism conjoins to the heuristic of risk to evaluate the correct diagnosis. It is common to trivialize some serious risk when they do not defy our threshold of control, while others are over-exaggerated. Although the statistics shows the industry of airplanes are safest ways of transportation, an accident causes serious damage to the trust of flying. Inversely, cars are very dangerous but our sense of control is higher than an airplane. Last but not least, Korstanje \& Skoll have explored the role of technology in the globalized economy in diverse studies. It is important not to leave behind that risk, like taboo, can develop a protective role for some communities. Basically, as a social construe not only risk varies on society, but also it alludes to the economic order (Skoll \& Korstanje, 2012; Korstanje \& Skoll, 2013). Zygmunt Bauman (2013b) argues convincingly that the sentiment of fear is fabricated by modernity to intellectualize the uncertainty, but mediating between humans. A closer look shows that postmodernity has advanced by the imposition of a liquid consuming life, which people and goods are equaled to similar conditions of exploitation. Risks, like fears, would serve as mechanism to interact with others, commoditizing the fears to mark those consumers who have made a bad decision. The state of perpetual emergency, Bauman adds, is oriented to curiosity to be accepted. The lay-citizen, in the postmodern world, looks to be accepted by other peers not to be excluded from the circle of massconsumption. The television show commoditizes disasters as a new form of entertainment. The sense of security of modern citizenry is only affected whenever their decision leads to be out of the consuming world; this represents the main fear of West today (Bauman, 2009; 2013). Since the real dangers are ignored by industrial societies, the disaster is only a question of time (Korstanje, 2009; 2011). In tourism and hospitality fields, risk-directed research has been adopted post $9 / 11$ (the attacks that shocked the world against World Trade Centre and other American targets) (Faulkner, 2001; Ritchie, 2004). Although, experts as Roehl and Fesenmaier (1992) have conducted, years earlier, innovative investigation in the matter of risk and the perception of international destinations, an exploding interest in risk as scientific object of study arose (Korstanje \& Olsen, 2011). In next section we will discuss the approaches and limitation of risk-perception in tourism studies.

\section{RISK IN TOURISM FIELDS}

Over years, specialists discussed the applicability of used methods to study risk. The quantitative-led vs. the qualitative-led approach led the debate to a deadline. While some studies evidence some problems of correlation among variables, others claim for the adoption of new techniques that help overcoming the algorithm inconsistencies. What is more than interesting to debate is to what an extent a correlation gains further explanatory power to understand the meaning of risk. Whether the question women perceive further risk than men, a qualitative view would shed the light this correlation is not given by genre differences, but in the way the woman is educated (to protect their home and family) (Zinn, 2010). Examples like this in the epistemology of risk research are everywhere. Quite aside from this, no less truth is tourism fields have adopted a quantitative-view respecting to risk research (Dolnicar, 2005a; 2005b). The second problem is given by the dichotomy between risk and perception. As Professor Svein Larsen put it, we may feel attraction for a destination even if it is dangerous. This does not happen because we are risk-prone travelers, but the worry and risk work in diverse levels for the mind. A worry activates an internal emotion to avoid certain objects, while risk are only associated to the cognitive structure of the subject (Larsen, 2007; 2009). The importance of image to cause stability within the tourist system was a key factor for scholarship to conduct riskresearch post 2001. Virus outbreaks, terrorist attacks, disease and natural disasters were enough motives to understand the world was changing to new states (McCartney, 2008). A serious attempt to classify risks has been done by Fuchs \& Reichel $(2010 ; 2004)$ in two main families. Those man-made risks should be separated from others triggered by nature. Risks associated to crime, terrorism, political instability and thefts are produced by us, while disasters, quakes, flood are determined by external forces. The success of a tourist destination depends on the trust generating levels produced by policy-makers. This is an important idea in the recovery policies simply because exhibits that planning plays a vital role in avoiding the collapse of destinations.

Starting from the premise, the industry faced a set of diverse dangers, the priorities to use riskmanagement to avoid disasters is of paramount importance so that the destination survives. Risk and disaster-management evaluate the potential steps to follow when the state of normalcy set the pace to emergency (Henderson 2008). Peter Tarlow (2011), one of the founding fathers of tourism safety, explains that visitors develop adverse sentiment to those countries where their safety cannot be granted. This affects the quality of life of many people and local agents who live from tourism. 
Combining deep psychological advances with risk-management plans should be the priorities of all states. The divorce of experts and politicians leaves a gap reducing the possibilities for a community to recover after a disaster hit.

Scholars who assert that risk perception is limited or enhanced by the trust travelers have were very popular in the first decade of the twenty-first century. They proposed that those travelers who were accompanied by relatives or friends perceive less risk than other groups. The sentiments of vulnerability are awakened when the travelers go beyond the security of home would be controlled by the social trust associated with accompanying companions (Roehl \& Fesenmaier, 1992; Yuan, 2005; Park \& Reisinger, 2010). A. Reichel, G. Fuchs, and N. Uriely (2007) found that those who prioritized the political instability as the main threat at time of vacationing, travelers in company of others are more likely to suffer physical wounds than single travelers.

The perception of self-vulnerability is potentiated by the lack of familiarity of unknown visited land. The fluency of language to ask for help or assistance is one of the first reasons for first world tourist to buy all inclusive package tours (Anderson, Juaneda \& Sartre, 2009). Similar outcomes were found by Qi, Gibson and Zhang (2009). Per an experiment, participants evidenced serious concerns at time of visiting a destination with different mother-tongue or in context of political instability. Paradoxically, this would be a problem for practitioners or planners who see the cultural differences between hosts and guest as the primary reason for violence and conflict (Sönmez, Apostolopoulos, \& Tarlow, 1999; Prideaux, Laws \& Faulkner, 2003; Abdel-Azim, 2010). George, Inbakaran, \& Poyyamoli propose an interesting model to understand the complex play between curiosity and personal safety. Tourism industry rests on two contrasting drives. On one hand, the self is motivated to escape towards new landscapes (tourist-motivation), but at the same time, there is a "nativist" motivation which appeals to the sense of security the visitor needs to feel safe. Whenever "nativist motivation overweight "tourist one", the self opts to return to home.

Ultimately, the role played by the media is vital to boost or decline destinations. Sometimes, the dreams of policy makers diluted in minutes because the risk-management programs lack of an efficient communication policy. Following Michael Hall's insights, the media covers news that shape the opinion public audience keeps respecting to what happens beyond our understanding. The communication policy post and pre disaster context can activate a great variety of responses. The attacks of World Trade Centre not only affected the American tourism industry, but also changed the ways other citizens developed to travel abroad (Hall 2002). The process of crises-management in tourism and hospitality experienced three important changes from $80 \mathrm{~s}$ up to date. The first was the economic recession surfaced in North America through 80s. This echoed in Asia with replication of domestic economies from 90s onwards. Finally, the most turbulent stage comes with the advent of $9 / 11$ in 2001 and the last financial crisis in 2008/2009. Based on the satisfaction on intangible services, tourism industry develops a high sensibility to crises and disasters (Hall 2010).

Geoffrey Skoll and Maximiliano Korstanje set forward a conceptual model to classify risk depending on its effects for public opinion. Public audience goes into panic when the event defies its possibilities to confront the period of crisis. The psychological impact of terrorism is amplified by media. Its effects cover the following points: a) control threshold, b) probability of repetition, and c) the status of the victims. The control threshold signals to the efficiency of the system to forecast the details for the next attack. The probability of repetition measures the mobilization of resources to prevent traumatic events. The likelihoods of repetition are proportionate to the effects of events that cannot be avoided. Finally, whenever victims are valorized by their high social status, the impact on the social imaginary is greater than cases where low status people are affected (Skoll and Korstanje, 2014a, 2014b).

\section{THE INSTABILITY IN GLOBAL ECONOMIES.}

Raoul Bianchi calls the attention to the problem of globalized risk. Tourism would play a pervasive role cementing the hegemonic practice of market to mark the ethnic-groups and other minorities. The globalization of risk, Bianchi adds, not only creates a state of instability that affects global tourism, but also expands disciplinary mechanism of control that objectifies the others. Non-western tourists are discriminated or scrutinized as a dangerous other whose presence is undesired (Bianchi 2007). Similar observations have been done a couple of years ago, by Scott Lash and John Urry. The hyper mobility engendered by the last modernity flourished following the technological advances in 
transport and information, but no less truth these shifts brought a new way of organizing economies. The modes and developed skills to access to certain types of mobilities confer different status to citizens. The real and symbolic barriers to move are of paramount importance to know the status of a person. In the hyper-mobile world, the cars and mobility have emptied the real geography producing a broader sentiment of omnipotence and control. The trajectory (exchange) of goods and humans (by the commerce or tourism) has created an empty space accelerating the decline of trust and social bond among persons. The history and tradition have been blurred in the hegemony of allegory. Today, the existent tension between experts and lay-people is enlarged. From this viewpoint, the decision before planning the holidays seems to be made according to the abstract information the client may collate. The personal experience and mouth-to mouth recommendations set the pace to new ways of indoctrinating the client's needs. In West, during XIX and XXth centuries, a new type of reflexibility has been established so that traveller may appreciate the visited landscapes, but this reflexibility is not hierarchical but aesthetical. The possibility for travellers not only to experience new sensations and landscapes, but to classify diverse geographical natures was, jointly to tourism, conducive to the assertiveness of cosmopolitism. The schedules of travels reproduced, in this vein, the aesthetic logic of modern society by limiting the presence of otherness to be a simple commodity to be consumed. The ability of travel agents was to create the risk to propose the solution. Risk plays a pervasive role because on one hand it confers further legitimacy to expertise-nets, but on the other, it poses as an instrument of communication. Experts, in this token are an interpreter, for lay- people to keep the trust in their institutions. In effect, travellers perceive as risks they previous beliefs communicated by experts. If times have shifted, the consumers today allude to more selective forms of consumption than other decades. The world has been drawn in geographies of domesticated spots and geographies of danger (wild-life zones) (Lash and Urry, 1993).

As the previous argument given, R. Bianchi and M. Stephenson (2014) in a recent seminal study exert a considerable criticism on the cultural mobility as it has been formulated in some circles of tourism industry. At the time first world tourists go through the vast geographies of this world, peripheral migrants are scrutinized, immobilized and monitored by the existent technology. The formation of political poles (cold-war) that leads the industry of travels to draw geography of submission. As this backdrop, tourism served to re-define the potentialities of citizenships as well as enhanced the nationalism in many sense. Not only tourism grew dramatically from 1960 to 1970 positing as one of the leading industries of the world but paved the ways for the accentuations of new material asymmetries inside the societies. Certainly, it is important not exaggerate the role of tourism in local economies nor accepting the promises of globalization as unquestionable truths. What Bianchi and Stephenson like to debate is to what extent tourism and globalization developed contrasting landscapes in the tourist-receiving countries. The material asymmetries prompted by tourism are fertile ground for the upsurge of violence and sentiments against West. The configuration of global elite instilled a new consciousness about culture, mobility and travels. As a maiden of empires, tourism encourages a double-edged mobility which is used as a disciplinary mechanism of control (Bianchi \& Stephenson, 2014).

Most likely, one of the troubling aspects of sociology and anthropology to understand risk rests on the dissapationately spirit to evaluate the consequences of crises on daily life of ordinary work-force. Nor interested in the social effects of crises, neither interested in intervening in risk-management plans, social scientists want to be privileged-witnesses of how people reacts to crises. The problem lies in the financial dependency of some peripheral countries respecting to tourism activates the needs to implement urgent plans of contingency before disasters, virus outbreaks in an ever-changing world. However, this poses a serious dilemma for the smooth functioning of industry. At the time, we desensitize to the appalling effects of terrorism or any other danger, further cruelty would be needed for captivating the nation-state's attention. This will lead to a spiral of violence that very well can be absorbed by different mechanisms of resiliency the society developed. For example, tourism offers some new landscape where human suffering, genocide or mass-death is the main attraction. It represents a valid effort for destination not to loose its attractiveness but it is important to remind that this policy has some costs. Not only tourism needs for the "other's pain" to subsist but its original function is distorted. Originally, tourism as any other a rite of passage was aimed at revitalizing the psychological frustrations of daily life in order for the society do not collapse. Now this original function has changed to new roles where relax or rest sets the pace to the quest for novelty. As we will see in the next sections, this opens the doorsteps to the end of tourism. 


\section{THE ENDS OF TOURISM}

In this section, we have exposed an exploratory thesis: the end of tourism is coming-up. Not only risks such as disasters, virus outbreaks or bloody civil wars are unproductive for leisure and tourism, but also the decline of current economy in developed countries after the financial crash in 2008. If our parents started their holidays after a long year of hard work, now holiday-makers ask for loans in the bank system to travel abroad. Some estimation reveals that we are not hyper- mobile as we thought, since only $1 \%$ of humankind is legally and financially invested to travel. This begs a more than interesting question, to what extent we can consider that visiting spaces of extreme suffering as Ground-Zero is under the sphere of ethics?.

This question is brilliantly addressed by Clare Weeden \& Kala Boluk in the book, Managing Ethical Consumption in Tourism.

Tourism is today one of the most promising industries in the world. However, the current tourist practices start to change towards new trends and forms, which certainly disorientate experts. The classic sun and beach product sets the pace to new forms of tourism where the concept of beautiness has been replaced by other morbid orientations. Dark-Tourism, Slum-tourism, Alcohol-tourism and sex tourism (among others) are gradually being posed as valid segments with a growing demand. This is the reason why Managing Ethical Consumption in tourism, a recent book edited by Clare Weeden and Karla Boluk is a recommended reading. In this text, editors formulate the needs to reconsider the role of ethics in tourism consumption, in a moment where the boundaries between ethics and law are blurred. While some social practices can be legal in some countries as sex with children or adolescent, they remain as unacceptable behaviour from ethics. Of course, despite the numerous studies in tourism consumption, ethics plays a marginal role. At some extent, tourist destinations, as Weeden \& Boluk put it, embrace some ethical values whether they can be commoditized or used to gain further advantages in an ever-changing market. The lack of interests for tourism ethics correspond with the belief that responsibility, an optional decision created along with "certification schemes". To put this in other terms, doing a responsible tourism is part of our duties as practitioners, but we are not legally forced. A second more epistemological reasons lies in the fact, studies in tourism ethics are scattered or published in humanitarian journals more associated to philosophy, sociology or anthropology instead of coordinating all produced knowledge in only one magazine or platform.

"What is unique about ethics is that more than any of these other fields of inquiry, it gets to the job of illuminating the tension that exists between what is good and bad, right and wrong, and authentic and inauthentic in tourism. It does this by forcing us to examine the human condition first, knowing something of ourselves, as a way to understanding tourism" (Preface Fennell 2014, $\mathrm{XVI})$.

From a broader sense, this fine book is self-oriented not only at instilling a hot but not for that less rational debate respecting to ethics in tourism, but pose as a valid attempt to create an all encompassing model that explains why ethics is so important for practitioners and scholarship. Although sustainability has recently monopolized a great variety of research which centre on failure in developmental programs, or negative effects of tourism in local communities, a profit-oriented spirit is embraced. At some extent, there is a clear disassociation between consuming and ethics, which explains why some tourists are insensitive to "the Other" suffering. Rather than being the result of some had hoc reflections or five-minute papers, this book is the result of years of fieldwork, which to our understanding will become in a seminal text in the next decades. The main thesis is that ethic tourism centers on a conceptual contradiction because the first term (ethic) signals to the moral rules that mark what is good from evilness but at the same time, tourism looks a recreational and selfish nature where the goals is the maximization of pleasure. It is important to note that ethical tourism not only helps reverting the old legacy of colonialism by exotizicing non-white natives, but overcoming the negative aftermaths of what Korstanje dubbed "the postmodern exploitative tactics of consumption", which consists in presenting the "other's suffering" to reinforce the supremacy of West over other cultures and civilization. Following this argument, Korstanje adds, these new trends as dark, thana-tourism or slum tourism are a direct result from the acceptance of "social Darwinism" where the survival of strongest is valorized over other possible alternatives. Visiting places of extreme 
poverty or suffering not only reminds we are living in the up-hill city, in an exemplary centre where others cannot enter, but serves as an ideological mechanism that makes us proud of our society, accelerating the social ties disorganization. Paradoxically, once we look for "Others", they are not genuinely recognized unless by strengthening our sentiment of superiority (Korstanje, 2015).

A second point of entry in this discussion relates to the financial problems to pay all inclusive packages offered by the market to those holiday-makers who prioritize their security. In a recent reedited book, entitled Tourism \& Development, Sharpley and Telfer acknowledged that from the first publication of their book in 2002 many things happen. Despite the promotion of tourism as vehicle towards development, little success reached the peripheral nations. The quandary is that overconsuming spots across over under-developed nations generates resentment and financial dependency, two serious problems for policy makers. In a world which is being exhausted, the system of production innovates in new sources to exploit. Beyond what lay people think tourism is not only a resilient activity, in which case community can use to face risks, but also it endorses wealth distribution to richest nations in North Hemisphere. Those southern countries which appeal to tourism for poverty relief, have limitations to develop a sustainable economy. Financial dependency surfaces as a result of two main issues. The lack of necessary infrastructure to welcome tourists needs from international investment, which unless regulated threatens the sustainability of region. Secondly, new destinations enter in competence with neighbors.

The moot point specialized literature ignores is that globalization and of course development are enterprises that undergo extinction after the sock and market crisis took hit US in 2008. Therefore, there would be substantial evidence not only tourism is dying, but also style of consuming are radically undermined. Our Grand-parents tend to work hard during the year to get their dream holidays while now we are pressed to pay our holidays in installments. The new flexible instrument of liberal market places consumers in debt to pay for the dream destination. Economy should be interpreted as a discipline that manage scarcity, whenever resources are abundant, prices and rates are lower than in times when the same resources are exhausted. Since tourism seems to be dying, now rates associated to leisure consumptions abruptly rose. In order for consumers to be engaged to the system, a new concept was introduced, authentic experience. Global tourists who love new experiences more authentic, pay exorbitant sum of money for what they consider "a real object of curiosity". However, now, the costs of mobilities reached levels almost impossible to pay. As Lash \& Urry puts it, we live into an "economy of signs, where exchanged objects are marked by a sacred-aura that condenses a great emotional charge. In a society where the rise of uncertainness is wreaking havoc, tourism serves as an ideological platform for escapement. As Bauman (2013a) discussed, one of the problems of capitalism consisted in commoditizing workers into goods, which can be exchanged in a marketplace (Bauman, 2013). The allegory of consumption was drawn outside the consumers. Legally, nation-states imposed a right to consume which upended the logic of labor. If workers earned money to save, now the mass-consumption leads them to be slaves of capital. In this case, consumers became in consumed objects. At a closer look Korstanje is not wrong when confirms that the right of holiday-making contemplated the idea that workforce needed rest and escapement from the alienatory atmosphere of factories. In postmodern capitalism, there is not place where to escape and it is a truism that vacations are not resulting from labor, but as a sign of status that divides exploited from exploiters (Korstanje 2015).

The rise of new more dangerous risks conjoined to the decline of post-modern means of production is enough to hint tourism is dying. Terrorism has advanced beyond the contours of Middle East at the doorstep of Anglo-Saxon Empire. One of the effects of 9/11 was not related to the economic loss tourism temporarily suffered, but to the adoption of a radical discourse, where "the Other" who is important for tourism should be subordinated to the cultural values of centre. This allegory paved the ways for the advent of a new radical ethnocentric view in regards of the periphery, which reinforced the protestant view of the manifest destiny, or the supremacy of US over the world. Terrorism has been successful not only in instilling the germen of fear in US soil, but introducing "preemption" as a valid mechanism of defense. As a result of this, US closed its borderlands initiating a new era of antihospitality. Tourism as an activity based on hospitableness has little probabilities to prosper in a world where the obsession for security and terrorism persist. 


\section{Conclusion}

The answer to the above formulated questions is not easy, and of course, it exhibits a fertile ground to be explored in other approaches. The ceaseless news about violence, cruelty, wars and deaths have serious negative impacts on audience worldwide. Though policy makers have devoted their time and efforts in looking for new alternative segments where death replaces the allegory of beautiness, giving as a result new products as dark-tourism, slum-tourism, disaster-tourism or doom-tourism, other problems arise. The curiosity for tourists in visiting spaces of mass death or extreme suffering contradicts not only its nature as a mechanism of revitalization and relaxes but may very well lead to narcissism which in fact is the end of tourism. If we pay attention enough to the evolution of dark tourism, we realize that far from being an interest for "others " pain" as specialized literature suggests, it exhibits an act of egoism. George $\mathrm{H}$ Mead, one of the fathers of symbolic interactionism, questioned why paradoxically many people are prone to read or listen of bad news presented by journalism, at the time they show preference by these types of news. What is our fascination for other's suffering? $\mathrm{He}$ assertively concludes that the self is configured by its interaction with others. This social dialectic alludes to anticipation and interpretation as two pillars of communication-process. The self feels happiness by other's suffering, because it represents a rite necessary to avoid or think in own pain. Starting from the premise the self is morally obliged to assist the "others" to reinforce its sentiment of superiority, Mead adds, this is the ethical nature of social relationship (Mead, 2009). The same applies for dark tourism.

In medieval times, death was present in almost all institutions, representation of the daily life but paradoxically, pilgrims may not be equaled to dark tourism sites by many reasons. Unlike modern sight-seers, medieval travellers move to sacred sites looking two important aspects to redeem their sins, forgiveness or the mediation of Saints to negotiate with God, a solution to their pains or big troubles. Although venerated, for medieval travellers death was not a problem like modern tourists, but also the beginning for a new better life. In this respect, dark tourism exhibits the opposite dynamic. "Secular tourists" are not interested in the life of others, nor in their heritage, or biography. They want to anticipate and avoid their own death. The specialized bibliography focuses on those modern tourists understand death through the lens of others. Rather, our argument goes in opposite direction. Tourists exorcise death ritualizing other's death to expand their own life expectances.

Zygmunt Bauman has reminded that life has no meaning without death. On his book Consuming life and Liquid Fear. The capitalist ethos has changed the mind of citizens, who passed being part of the production machinery. As commodities, workers are exploited to congeal the mass-consumption encouraged by capitalism. The big brother is an example how people enter in competence, as commodities, to be selected and bought by others. Participants in this reality show know that only one will win, and the rest will die. Big Brother, for Bauman, emulates the life in capitalist societies which enhance the style of life of few by producing pauperization for the whole. The modern state set the pace to the advent of liberal market to monopolize the sense of security for people. This does not mean that states are unable to keep the security, but also the market is re-channelling the consumption by the imposition of fear. If human disasters as Katrina show the pervasive nature of capitalism which abandoned thousands of pour citizens to death, no less truth is that the "show of disaster" unbinds of responsibilities for the event. The sense of catastrophe, like death, serves to cover the inhuman nature of capitalism (Bauman, 2008; 2013a). This society only has an answer to crisis, when its economic system is at risk. Since the real reason for disaster are ignored by the allegory of death, which persisted in the media and famous TV series where technicians and forensic experts look to solve the crime, the disaster comes sooner or later. What we really know on the real causes of Auschwitz or 9/11?, may a simple museum explain us the complexity of human nature?. Bauman will say, absolutely not. Any attempt to sacralise the dying as a spectacle, at the bottom, represents the prelude of its neglect. Last but not least, dark tourism is not different than other issues as FIFA World Cup, reality-shows, Big Brother and so forth. They proclaim ideologically that only one may be the winner. As a result of this, the climate of labor is vulnerated in favor of an eternal competence where workers are challenged to be co-active managers of their own destiny. In shark opposition to the medieval traveler, dark tourism consumers seek to reinforce their life as their other's death. In contrast to what the specialized literature suggests, dark tourism reinforces the modern egocentrism to enjoy in brother's tragedy. Protestantism has brought the idea that life should be symbolized as a great trace where only one will be the winner. Of course, this means that the rest will loose. If tragedy confers to survivors the aura of exemplary civilization, it runs higher costs. Happiness for the other's death is a 
sign we still remain in contention for a final fight. From the Big Brother to The Hunger Games, the salvation of one by the ruin of whole has been a constant ideology of our modern world. The ethics of dark tourism emulates a new economic form of exploitation that characterizes the capitalist-ethos, which evinces that tourism is at the final stage.

\section{REFERENCES}

Abdel-Azim, T. S. (2010). "The Relationship between the perception of Risk and the Decision Making process of Travel of French Tourists. The case of Egypt". Tourismos: an international Multidisplinary Journal of tourism. Vol. 5 (2): 29-47.

Anderson, W. Juaneda, C. \& Sastre, F. (2009). "Influences of pro-all-inclusive Travel Decisions". Tourism Review. Vol. 64 (2): 4-18.

Bauman, Z. (2008). Liquid fear. Buenos Aires, Paidos.

Bauman, Z. (2009). "Freudian Civilization revisited - or whatever happened to the reality principie?". Anthopological Psychology, No 21: 1-9.

Bauman, Z. (2013a). Consuming life. New York, John Wiley \& Sons.

Bauman, Z. (2013b). Liquid fear. London, John Wiley \& Sons.

Beck, U. (2006). Risk society, towards a new modernity. Buenos Aires, Paidos.

Beck, U. (2011). "Convivir con el Riesgo Global". En La Humanidad Amenazada: gobernar los riesgos globales. D. Innerarity \& Solana, J (Editores). Madrid, Paidos, pp. 21-32.

Bianchi, R. (2007). "Tourism and The Globalization of Fear: analyzing the politics of risk and (in)security in global travel". Tourism and Hospitality Research. Vol. 7 (1): 64-74.

Bianchi R. \& Stephenson, M. (2014) Tourism and Citizenship: rights, freedoms and responsibilities in the global Order. Abingdon, Routledge.

Blake, A., \& Sinclair, M. T. (2003). Tourism crisis management: US response to September 11. Annals of Tourism Research, 30(4), 813-832.

Cohen, E., \& Neal, M. (2010). Coinciding crises and tourism in contemporary Thailand. Current Issues in Tourism, 13(5), 455-475.

Dolnicar, S. (2005a). "Fear Segment in tourism". CD Proceedings of the 14 International Research Conference of the Council for Australian University and Hospitality Education. CAUTHE. 1-5 Febrero de 2005, Australia.

Dolnicar, S. (2005b). "Understanding barriers to leisure travel, tourists fears as marketing basis". Journal of Vacation Marketing, 11 (3): 197-208.

Duclos, D. (1987). "Le Risque: une construction sociale?". En J. Fabiani, y J Thyes. La Societeé Vulnerable. Paris, Ecole Normale Superieure, pp. 91-92.

Faulkner, B. (2001). Towards a framework for tourism disaster management. Tourism Management, 22(2), 135-147.

Fennell D. A (2014) "Foreword". In Managing Ethical Consumption in Tourism. C. Weeden \& K. Boluk (editors). New York, Routledge, pp. xv-xvii

Fuchs, G. \& Reichel, A. (2004). "Cultural Differences in tourist destination risk perception: an exploratory study". Tourism. Vol. 52 (1): 21-37.

Fuchs, G. \& Reichel, A. (2010). "Health Tourists Visiting a Highly Volatile Destination”. Anatolia, an international Journal of Tourism and Hospitality Research. Vol. 21 (2): 205-226.

Gale, T. (2008) 'The end of tourism or endings of tourism?', in Burns, P. and Novelli, M. (eds) LocalGlobal Connections. Wallingford: CABI, 1-14.

George, B, Inbakaran, R. \& Poyyamoli, G. (2010). "To Travel or Not to travel: towards understanding the theory of nativistic motivation". Tourism, an international interdisciplinary Journal. Vol. 58 (4): 395-407.

Giddens, A. (1991). Modernity and Self-Identity: Self and Society in the Late Modern Age. California, Stanford University Press.

Giddens, A. (1999). The Consequences of Modernity. Madrid, Alianza Editorial.

Giddens, A. (2000). Run Away World: how globalization is reshaping our lives. Madrid, Taurus.

Hall, M. (2002). "Travel Safety, terrorism and the media the significance circle of the issue attention cycle". Current Issues in Tourism, 5 (5): 458-466. 
Hall, M. (2010). "Crisis Events in Tourism: subjects of crisis in Tourism". Current Issues in Tourism. Vol. 13 (5): 401-417.

Henderson, J. C. (2008). "Managing Crises: UK Civil Aviation, BAA airpots and the August 2006 terrorist Threat". Tourism and Hospitality Research. Vol. 8 (2): 125-136.

Korstanje, M. (2009). "Re-visiting risk perception theory in the context of travel". E-Review of Tourism Research, 7(4), 68-81.

Korstanje, M. E. (2011a). "The fear of traveling: a new perspective for tourism and hospitality". Anatolia, 22(2), 222-233.

Korstanje, M. E. (2011b). Why risk why now? Conceptual problems around the risk perception in tourism industry. RBTur, 5(1): 4-22

Korstanje, M (2015) A Difficult World, examining the roots of Capitalism. New York, Nova Science publishers.

Korstanje, M. E., \& Olsen, D. H. (2011). The discourse of risk in horror movies post 9/11: hospitality and hostility in perspective. International Journal of Tourism Anthropology, 1(3), 304-317.

Korstanje, M. E., \& Skoll, G. (2013). "An Essay on the Social Costs and Benefits of Technology Evolution". Human \& Social Studies. Research and Practice, 2(2), 13-39.

Mccartney, G. (2008). "Does one culture all think the same?. An investigation of destination image perceptions from several origins". Tourism Review. Vol. 63 (4): 13-26.

Mead, G. H. (2009). Mind, self, and society: From the standpoint of a social behaviourist (Vol. 1). Chicago, University of Chicago press.

Lash, S. M., Urry, S. L. J., \& Urry, J. (1993). Economies of signs and space (Vol. 26). London, Sage.

Larsen, S. (2007). "Aspects of a Psychology of the Tourist Experience". Scandinavian Journal of Hospitality and Tourism. Vol. 7 (1): 7-18.

Larsen, S. (2009). "What Tourists worry about: construction of a scale measuring tourist worries". Tourism Management. Vol. 30: 260-265

Luhmann, N. (2006). Sociología del Riesgo (Sociology of Risk). México, Universidad Iberoamericana.

Qi, X. C. Gibson, H \& Zhang, J. (2009). "Perception of risk and Travel Destinations. The case of China and the Beijing Olympic Games". Journal of Sports \& Tourism. Vol. 14 (1): 43-67.

Park, K. and Reisinger, Y. (2010). "Differences in the perceived influence of natural disasters and travel risk on international travels". Tourism Geographies. Vol. 12 (1): 1-24.

Pforr, C., \& Hosie, P. (Eds.). (2009). Crisis management in the tourism industry: beating the odds?. London, Ashgate Publishing, Ltd..

Prideaux, B., Laws, E., \& Faulkner, B. (2003). "Events in Indonesia: exploring the limits to formal tourism trends forecasting methods in complex crisis situations". Tourism management, 24(4), 475-487.

Quarantelli, E. (1975). "Panic Behavior: some empirical observations".Disaster Research Center, Preliminary Paper 20

Quarantelli, E. (1982). "People's reactions to emergency warnings".Disaster Research Center, Preliminary Paper 75.

Quarantelli, E. (1990). "The Mass media in disasters in the UnitedStates". Disaster Research Center, Preliminary Paper 1990.

Quarantelli, E. (2001). "The Sociology of Panic". Disaster Research Center, Preliminary Paper 283

Reichel, A. Fuchs, G. and Uriely, N (2007). "Perceived risk and the non-instituonalized tourist role: the case of Israeli student ex backpackers". Journal of Travel Research. Vol. 46: 217-226.

Ritchie, B. W. (2004). Chaos, crises and disasters: a strategic approach to crisis management in the tourism industry. Tourism management, 25(6), 669-683.

Ritchie, B. W. (2009). Crisis and disaster management for tourism. Bristol: Channel View Publications.

Sharpley, R \& Telfer D. (2015) Tourism \& Development: concepts and Issues. 2nd edition. Bristol, Channel view publications.

Skoll, G. R., \& Korstanje, M. E. (2012). Risks, totems, and fetishes in Marx and Freud. Sincronía, (2), $1-27$. 
Skoll, G. R., \& Korstanje, M. E. (2014a). Points of Discussion around 9/11, terrorism and tourism revisited. e-Review of Tourism Research, 11(1-2), 1-17

Skoll, G. R., \& Korstanje, M. E. (2014b). Terrorism, homeland safety and event management. International Journal of Hospitality and Event Management, 1(1), 95-110.

Sönmez, S. F., Apostolopoulos, Y., \& Tarlow, P. (1999). "Tourism in crisis: Managing the effects of terrorism". Journal of Travel Research, 38(1), 13-18.

Sunstein, C (2006). Risk and Reason. Safety, law and environment. Buenos Aires, Katz.

Roehl, W. and Fesenmaier, D. (1992). "Risk Perceptions and Pleasure Travel: an exploratory analysis". Journal of Travel Research, Vol. 30 (4): 17-29.

Tarlow, P. (2011). Tourism disaster management in an age of terrorism. International Journal of Tourism Anthropology, 1(3), 254-272.

Tarlow, P. \& Korstanje M. (2013) "Disasters, tourism, and mobility: the case of Japan Earthquake". Pasos, revista de Turismo y Patrimonio Cultural. Vol. 11 (3): 17-32

Tierney, K. (1994). "Sociology's Unique Contributions to the Study of Risk". Disaster Research Center, Preliminary Paper, 204.

Weeden, C \& Boluk K (2014) Managing Ethical Consumption in Tourism. New York, Routledge.

Yuan, M. (2005). "After September 11: determining its Impacts on Rural Canadians travel to U.S". Ereview of tourism Research, 3 (5): 103-108.

Zinn, J. O. (2010). "Biography, Risk and Uncertainty - is there common ground for biographical Research and Risk Research". FQS, Forum, Qualitative Social Research. Vol. 11 (1). Paper 15

\section{AUTHORS' BIOGRAPHY}

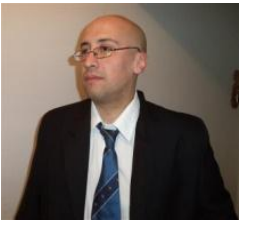

Korstanje Maximiliano Visiting Lecturer at CERS. University of Leeds UK. Reader at Economics, University of Palermo, Argentina. He is editor in chief of International Journal of Safety and Security in Tourism (UP Argentina) and International Journal of Cyber Warfare and Terrorism (IGI-GlobalUS). Korstanje is subject to biographical records for Marquis Who`s Who in the World since 2009. He had nominated to 5 honorary doctorates for his contribution in the study of the effects of terrorism in tourism. In 2015 he was awarded as Visiting Research Fellow at School of Sociology and Social Policy, University of Leeds, UK. Korstanje was visiting Fellow at UDET, Ecuador, University Silva Henriquez Chile and University of Leeds UK.



Lourdes Cisneros Mustelier Dean of Tourism. University of la Habana Cuba. She is a well-recognized specialist in Sustainability, risk perception and Tourism planning. In her recent years, Mustelier focused the work on issued relating to development and heritage. She awarded the prize ALMA MATTER 2009 given by the University of La Habana. She was worked in a plenty of position in the University of la Habana and is considered a master key note speakers in her area of specialization. Lourdes Mustelier was visiting fellow at University of Andalucia, University of Valencia Spain, University of Cartagena de Indias, Colombia. University of Xian, China and University of California at Fullerton, US. 